\title{
Autoantibodies Toward the Angiotensin 2 Type 1 Receptor: A Novel Autoantibody in Alzheimer's Disease
}

\author{
Lasse M. Giil ${ }^{\mathrm{a}}$, Einar K. Kristoffersen ${ }^{\mathrm{b}, \mathrm{c}}$, Christian A. Vedeler ${ }^{\mathrm{d}}$, Dag Aarsland ${ }^{\mathrm{e}, \mathrm{f}, *}$, \\ Jan Erik Nordrehaug ${ }^{\mathrm{b}, \mathrm{g}}$, Bengt Winblad ${ }^{\mathrm{e}}$, Angel Cedazo-Minguez ${ }^{\mathrm{e}}$, Anders Lund ${ }^{\mathrm{b}}$ \\ and Tove Ragna Reksten ${ }^{\mathrm{c}, \mathrm{f}}$ \\ ${ }^{a}$ Department of Internal Medicine, Haraldsplass Deaconess Hospital, Bergen, Norway \\ ${ }^{\mathrm{b}}$ Institute of Clinical Science, University of Bergen, Bergen, Norway \\ ${ }^{\mathrm{c}}$ Department of Immunology and Transfusion Medicine, Haukeland University Hospital, Bergen, Norway \\ ${ }^{\mathrm{d}}$ Institute of Clinical Medicine, University of Bergen, Bergen, Norway \\ ${ }^{\mathrm{e}}$ Department of Neurobiology, Care Sciences and Society, Center for Alzheimer Research, \\ Division of Neurogeriatrics, Karolinska Institutet, Stockholm, Sweden \\ ${ }^{\mathrm{f}}$ Centre for Age-Related Diseases (SESAM), Stavanger University Hospital, Stavanger, Norway \\ ${ }^{\mathrm{g}}$ Department of Cardiology, Stavanger University Hospital, Stavanger, Norway
}

Handling Associate Editor: Henrik Zetterberg

Accepted 27 April 2015

\begin{abstract}
.
Background: Autoantibodies with agonist function are described in cardiovascular disorders. Since vascular risk factors are associated with an increased risk for Alzheimer's disease (AD), we investigated a potential association between antibodies to the angiotensin 2 type 1 receptor (anti-AT1R) and AD.

Objective: The primary objective of this study was to investigate the association between anti-AT1R and AD. The secondary objective was to investigate the association between clinical or biomarker features of AD and anti-AT1R.

Methods: Samples from patients with mild AD participating in a longitudinal study in Western Norway $(n=92,65$ [71\%] females, mean age 74.8 [range 50-89]) and age- and gender-matched healthy controls $(n=102)$ were included. Cerebrospinal fluid (CSF) AD biomarkers were assessed in a subgroup of patients. Patients were examined annually, including Mini-Mental State Examination. ELISA was used to measure anti-AT1R in serum. Non-parametric tests were used for statistical calculations and a $p<0.05$ was considered significant.

Results: AD patients had significantly higher levels of anti-AT1R compared with healthy controls $(10.2 \mathrm{U} / \mathrm{mL}$ versus $8.1 \mathrm{U} / \mathrm{mL}$, $p=0.04)$. This difference was found only in patients without hypertension and diabetes. Anti-AT1R levels correlated with CSF total tau $(p=0.03)$ and phosphorylated tau $(p=0.03)$ levels, and inversely with blood pressure in AD (Spearman $\mathrm{R}-0.277$, $p=0.008)$.

Discussion: AD is associated with increased levels of anti-AT1R, and the antibodies correlated with CSF total, and phosphorylated tau levels. Further research is needed to understand the blood pressure response in AD without hypertension and a potential link between tau and anti-AT1R in AD.
\end{abstract}

Keywords: AT1R, autoimmunity, dementia, neurodegeneration

\section{INTRODUCTION}

*Correspondence to: Dag Aarsland, Department of Neurobiology, Care Sciences and Society (NVS), H1, Division of Neurogeriatrics, Novum PI5, 14157 Huddinge, Sweden. Tel.: +47 97575804; Fax: +46 8311101; E-mail: daarsland@gmail.com.

Alzheimer's disease (AD) is the most common neurodegenerative disorder and the most common cause of dementia. Hallmarks of AD neuropathology are 
accumulation of extracellular amyloid- $\beta(A \beta)$ in senile plaques, intraneuronal phosphorylated tau proteins in tangles, and activation of microglial cells [1]. In addition to age, acquired cardiovascular disorders, such as mid-life hypertension [2], diabetes [3], atrial fibrillation [4], and atherosclerotic disease [5], increase the risk of later development of AD. These risk factors are known to be associated with agonist antibodies to key $\mathrm{G}$ protein-coupled receptors (GPCR) of the vasculature and autonomic nervous system, such as alpha 1 adrenoceptors ( $\left.\alpha_{1}-\mathrm{AR}\right)$, angiotensin 2 type 1 receptors (AT1R), beta 1 adrenoceptors ( $\left.\beta_{1}-A R\right), M 2$ muscarinic receptors $\left(\mathrm{M}_{2}-\mathrm{MR}\right)$, and endothelin-1-type A receptors (ET1A) [6-10]. Anti-GPCR antibodies such as anti- $\beta_{2}-A R$ and anti- $\alpha_{1}-A R$ were recently found to be associated with $\mathrm{AD}$ and vascular dementia [11].

AT1R have important functional roles in the cerebral microcirculation and in the brain itself. They regulate blood-brain barrier (BBB) permeability [12] and are linked to neuroinflammation, neuronal differentiation and neurite growth [13]. Importantly, AD patients taking angiotensin receptor blockers were found to have reduced AD-related pathology postmortem [14]. In animal studies, stimulation of the angiotensin system increases leukocyte adhesion, increases permeability of the $\mathrm{BBB}$, induces oxidative stress in the microcirculation of the brain [15], and leads to an increase in $A \beta$ [16] and tau [17] pathologies. Neuronal cell death is also strongly linked to the presence of immunoglobulin $\mathrm{G}$ in $\mathrm{AD}$ patients' brains. In addition, immunoglobulin $G$ passes over the BBB to a larger extent in $\mathrm{AD}$, potentially gaining central access for functional autoantibodies [18]. To our knowledge AT1R antibodies have not yet been studied in vivo in AD.

There are several possible mechanisms by which AT1R antibodies may influence AD pathology, and the antibodies might represent biomarkers for patient that might benefit from treatment with angiotensin receptor blockers. The primary objective of this study was to test whether AT1R antibodies are increased in patients with mild AD compared to healthy elderly subjects. The secondary objectives were to explore the association of anti-AT1R with clinical features, longitudinal endpoints, APOE genotype and biomarker features of AD.

\section{METHODS}

\section{Subjects}

Patients were recruited from the Dementia study in Western Norway (DemVest, described in [19]), where patients with mild dementia were recruited dur- ing 2005-2007 from three participating hospitals in Rogaland and Hordaland counties in Norway. Mild dementia was defined as a minimum Mini-Mental State Examination (MMSE) score of 20 or a Clinical dementia rating scale score of 1 . AD patients were diagnosed according to criteria from The National Institute of Neurological and Communicative Disorders and Stroke-Alzheimer's Disease and Related Disorder Association after a detailed medical history, standardized clinical examination by a trained research clinician with long experience in geriatric psychiatry, neurology, or geriatric medicine. Cardiac and other medical diagnoses and treatments were recorded. Vascular dementia was defined as clinical or radiological evidence of cerebrovascular disease and a temporal relationship between cerebrovascular disease and dementia, according to the consensus criteria [20]. Exclusion criteria were acute delirium or confusion, terminal illness, recently diagnosed major somatic illness, and previous bipolar or psychotic disorder.

From this study, 92 patients with AD were included. Patients were prospectively followed with annual assessments, including MMSE score, and duration of survival from baseline, for a total of 5 years. The comprehensive and standardized diagnostic procedures are described elsewhere [21]. Blood pressure [22], CSF [23] $(n=30)$, and APOE [24] were analyzed as previously described. As controls, 102 subjects with MMSE scores above 28 and no recent major neurological or cardiovascular disease were recruited from senior centers in Bergen during 2014. They went through a clinical interview, as well as a clinical and neurological examination. Blood pressure and MMSE scores were registered. Hypertension, cardiac disease, stroke, and diabetes were recorded for both groups.

\section{Anti-AT1R measurements}

Serum samples were collected at baseline only and stored at $-80^{\circ} \mathrm{C}$. Serum anti-AT1R antibodies were measured in duplicates using a solid-phase, sandwich enzyme-linked immunosorbant assay (ELISA) (Catalog \#: EIA-AT1R, OneLambda, CA, USA) as recommended by the manufacturer. Absorbance was measured with an ELISA plate reader (Multiskan Ex Primary EIA V. 2.3) at $450 \mathrm{~nm}$. Samples over the standard curve were assayed again at higher dilution factor and if still over the standard curve, given a value consistent with the OD. High-binding antibodies were defined at $>17 \mathrm{U} / \mathrm{mL}$, low-binding antibodies as 10-17 $\mathrm{U} / \mathrm{mL}$, and samples with less than $10 \mathrm{U} / \mathrm{mL}$ were considered negative, as suggested by manufacturer. 


\section{Statistics}

Anti-AT1R values are expressed as medians with interquartile range, other measures as means. Analyses were performed by use of Prism (GraphPad Software, La Jolla, CA, USA) or IBM SPSS Statistics 22.0 (SPSS Inc., Chicago, IL, USA). Based on data distributions, non-parametric (Mann-Whitney tests and Spearman correlations) were used for statistical calculations involving anti-AT1R values. Parametric tests were used for blood pressure and MMSE, and a $p$-value below 0.05 was considered significant.

\section{Ethics}

The study was approved by the Regional Ethics Committee (REK approval no.: 2010/633) and the recruitment of controls after a notification of change. Patients and controls provided written consent to participate in the study after procedures had been explained in detail, and in case of patients with dementia, also to a caregiver.

\section{RESULTS}

The characteristics of AD and control subjects are shown in Table 1. The groups differed on MMSE score as expected. Mean systolic blood pressure was higher in the AD group, but groups did not differ significantly regarding age, gender, co-morbidities, and drug use. The median (IQR) CSF values for $A \beta_{42}$ were 191 (IQR 85), for total tau (t-tau) 425 (442), and for phosphorylated tau (p-tau) 62 (46). A significantly higher proportion of AD patients (54\%) were antiAT1R positive compared to controls (35\%) (Fisher's exact test, $p=0.009$ ), and the levels were significantly elevated in AD patients compared with normal controls (Fig. 1), with median AT1R antibody levels of 10.22 [IQR 7.62-13.73] U/mL in patients and 8.08 [IQR 5.54-12.26] U/mL in controls $(p=0.018)$. The

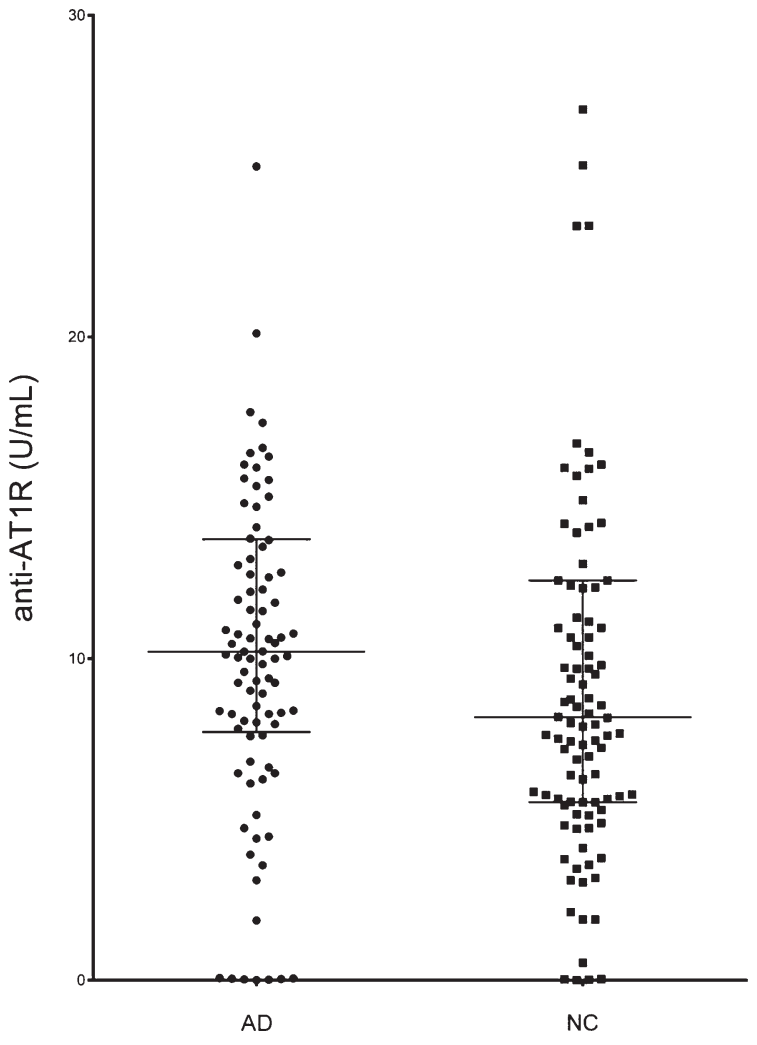

Fig. 1. Alzheimer's disease (AD) patients have significantly higher levels of circulating serum anti-AT1R compared with normal controls (NC). (Lines indicate median and IQR, 14 outliers with anti-AT1R $>30 \mathrm{U} / \mathrm{mL}$ have been omitted from graph. There were 6 from the AD group and 8 from controls).

significantly different distribution is maintained when comparing frequencies of high positive, low positive, and negative (Chi-square, $p=0.02$ ).

Anti-AT1R levels were found to have an inverse relationship with blood pressure in AD patients (Spearman's rho $-0.277, p=0.008$ ) but not in controls (Fig. 2). When excluding patients with both a cardiac disorder and hypertension, the inverse relationship was maintained (Spearman's rho $-0.369, p=0.02$ ) in

Table 1

Subject demographics

\begin{tabular}{|c|c|c|c|c|c|c|c|c|c|}
\hline & $\begin{array}{c}\text { Age } \\
(\text { mean } \pm \text { SD) }\end{array}$ & $\begin{array}{c}\text { Gender } \\
(\mathrm{M} / \mathrm{F})\end{array}$ & $\begin{array}{c}\text { MMSE } \\
(\text { mean } \pm \text { SD) }\end{array}$ & $\begin{array}{c}\text { Systolic } \\
\text { blood } \\
\text { pressure } \\
(\text { mean } \pm \text { SD) }\end{array}$ & $\begin{array}{l}\text { Hypertension } \\
\text { (yes/no) }\end{array}$ & $\begin{array}{l}\text { Cardiac } \\
\text { disease } \\
(\text { yes/no) }\end{array}$ & $\begin{array}{l}\text { Hypertension } \\
\text { and cardiac } \\
\text { disease } \\
\text { (yes/no) }\end{array}$ & $\begin{array}{c}\text { Drugs acting } \\
\text { on cardiovascular } \\
\text { system } \\
\text { (ATC “C”') }\end{array}$ & $\begin{array}{l}\text { Drugs acting } \\
\text { on the renin- } \\
\text { angiotensin } \\
\text { system } \\
\text { (ATC "C09") }\end{array}$ \\
\hline $\begin{array}{l}\text { AD patients } \\
(n=92)\end{array}$ & $74.8 \pm 7.7$ & $26 / 66$ & $23.8 \pm 2.2^{*}$ & $155.4 \pm 18.8^{\S *}$ & $39 / 52^{\#}$ & $26 / 62^{\S}$ & $16 / 73^{\&}$ & $50(56 \%)^{a}$ & $17(19 \%)$ \\
\hline $\begin{array}{l}\text { Normal controls } \\
\quad(n=102)\end{array}$ & $73.5 \pm 7.5$ & $27 / 75$ & $29.3 \pm 1.0$ & $133 \pm 13.5$ & $33 / 69$ & $16 / 86$ & $11 / 91$ & $40(39 \%)$ & $19(18 \%)$ \\
\hline
\end{tabular}


Table 2

Anti-AT1R levels in clinical subgroups

\begin{tabular}{|c|c|c|c|c|c|c|c|c|}
\hline & \multicolumn{4}{|c|}{ Alzheimer's disease patients } & \multicolumn{4}{|c|}{ Normal controls } \\
\hline & $\begin{array}{l}\text { Cardiac } \\
\text { Disease }\end{array}$ & Hypertension & Stroke & Diabetes & $\begin{array}{l}\text { Cardiac } \\
\text { Disease }\end{array}$ & Hypertension & Stroke & Diabetes \\
\hline $\mathrm{n}(\mathrm{pos}): \mathrm{n}(\mathrm{neg})$ & $26: 62$ & $39: 52$ & $10: 77$ & $7: 82$ & $16: 86$ & $33: 69$ & $5: 97$ & 3:99 \\
\hline Anti-AT1R & $10.4 \mathrm{U} / \mathrm{mL}$ & $10.0 \mathrm{U} / \mathrm{mL}$ & $11.7 \mathrm{U} / \mathrm{mL}$ & $8.1 \mathrm{U} / \mathrm{mL}$ & $8.6 \mathrm{U} / \mathrm{mL}$ & $8.2 \mathrm{U} / \mathrm{mL}$ & $8.2 \mathrm{U} / \mathrm{mL}$ & $7.5 \mathrm{U} / \mathrm{mL}$ \\
\hline Median (pos) & [7.6-14.8] & [6.8-14.1] & {$[5.1-15.1]$} & {$[3.1-10.1]$} & [3.0-11.9] & {$[5.8-12.4]$} & {$[1-10.2]$} & {$[5.1-45.6]$} \\
\hline Anti-AT1R & $10.0 \mathrm{U} / \mathrm{mL}$ & $10.2 \mathrm{U} / \mathrm{mL}$ & $10.0 \mathrm{U} / \mathrm{mL}$ & $10.5 \mathrm{U} / \mathrm{mL}$ & $8.0 \mathrm{U} / \mathrm{mL}$ & $8.0 \mathrm{U} / \mathrm{mL}$ & $7.2 \mathrm{U} / \mathrm{mL}$ & $8.2 \mathrm{U} / \mathrm{mL}$ \\
\hline Median (neg) & {$[7.6-13.2]$} & {$[8.0-13.4]$} & {$[7.9-13.5]$} & {$[7.9-14.4]$} & {$[5.5-12.4]$} & {$[5.1-12.3]$} & {$[5.5-12.4]$} & [5.5-12.3] \\
\hline$p$-value & 0.47 & 0.70 & 0.77 & 0.05 & 0.76 & 1 & 1 & 1 \\
\hline$p$-value pos $A D$ versus $N C$ & 0.11 & 0.19 & 0.27 & 1 & & & & \\
\hline
\end{tabular}

Median, IQR levels and $p$-value (Mann-Whitney) for anti-AT1R in subgroups with or without a disease associated with anti-AT1R. There are missing data in the AD subgroups. Cardiac disease $(n=4)$, hypertension $(n=1)$, stroke $(n=5)$, and diabetes $(n=3)$.

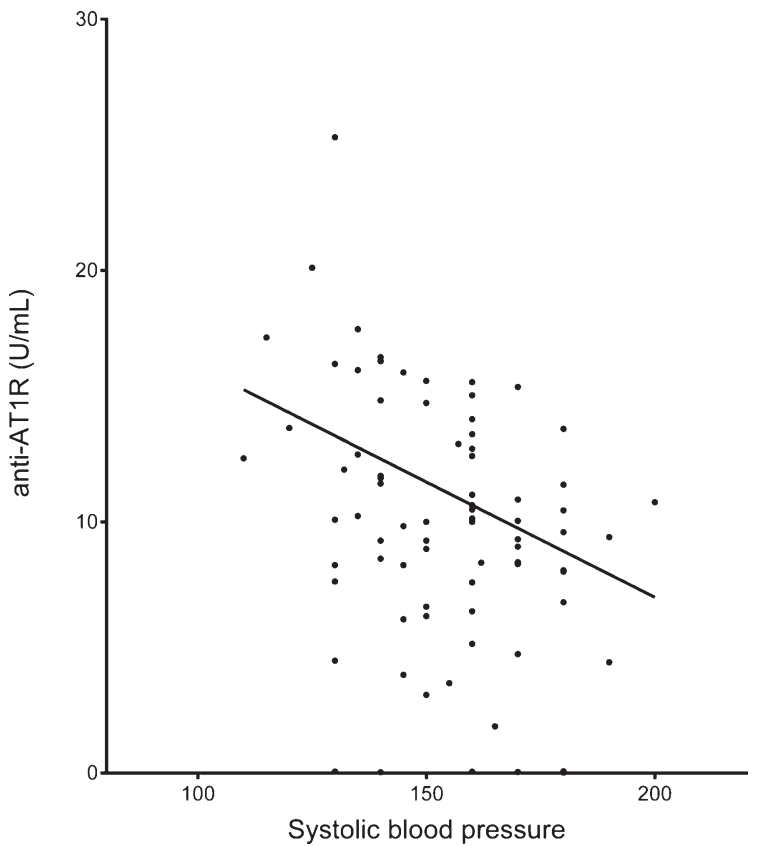

Fig. 2. AT1R antibodies correlated negatively with systolic blood pressure in AD patients ( $n=87,6$ outliers with anti-AT1R $>30 \mathrm{U} / \mathrm{mL}$ have been omitted from graph).

the remaining $\mathrm{AD}$ patients $(n=42)$. There was no significant difference in AT1R antibody levels in AD patients with or without known cardiac disease (10.4 $\mathrm{U} / \mathrm{mL}$ versus $10.0 \mathrm{U} / \mathrm{mL})$, known hypertension (10.0 $\mathrm{U} / \mathrm{mL}$ versus $10.4 \mathrm{U} / \mathrm{mL}$ ), or a clinical history of stroke $(12.6 \mathrm{U} / \mathrm{mL}$ versus $10 \mathrm{U} / \mathrm{mL})$. However, for diabetes $(8.1 \mathrm{U} / \mathrm{mL}$ versus $10.5 \mathrm{U} / \mathrm{mL})$, there was a trend toward lower anti-AT1R level among the patients with $\mathrm{AD}$, but without diabetes. Median levels and IQR for these subgroups are presented for $\mathrm{AD}$ and controls in Table 2. There were between 1-5 patients with missing data in the AD subgroup analyses (Table 2, legend). When performing the analyses among patients with or without hypertension, cardiac disease or diabetes separately, we found a clear association. AD and controls differed significantly only among cases without hypertension ( $p=0.04)$ and diabetes $(p=0.008)$, and at trend level $(p=0.08)$ among those without cardiac disease, whereas among those with these diseases there were no significant differences between $\mathrm{AD}$ and controls.

Serum anti-AT1R correlated significantly with t-tau (Spearman rho 0.39, $p=0.03$ ) and p-tau (rho 0.40, $p=0.03$ ), but not with CSF A $\beta^{42}$ (Fig. $3, N=30$ ). AntiAT1R levels were not associated with rate of MMSE decline (mean decline -2.6 points/year), survival, or with APOE genotype (data not shown).

\section{DISCUSSION}

We describe for the first time the occurrence of AT1R antibodies in patients with AD. Anti-AT1R antibodies were found in $53 \%$ of $\mathrm{AD}$ patients and in $35 \%$ of matched normal controls. The frequency found in our controls is within the range of previously observed AT1R antibody levels in pre-renal transplant patients $(23-45 \%)[25,26]$. Ten percent of both patients and controls presented high anti-AT1R levels. We did not identify any associations between poor prognostic outcomes and features indicating a more severe disease in these patients. Anti-AT1R have been reported to be associated with cardiac disease [27], hypertension [28], and diabetes [29], and thus these common diseases might confound the findings. Thus, when analyzing patient subgroups with or without such diseases, a clear pattern emerged. Differences between AD and controls were observed only among patients without hypertension, diabetes, or cardiac disease, strengthening the hypothesis that the differences in anti-AT1R levels are related to AD itself rather than to confounding diseases. There is, however, no significant difference between anti-AT1R levels between patients 

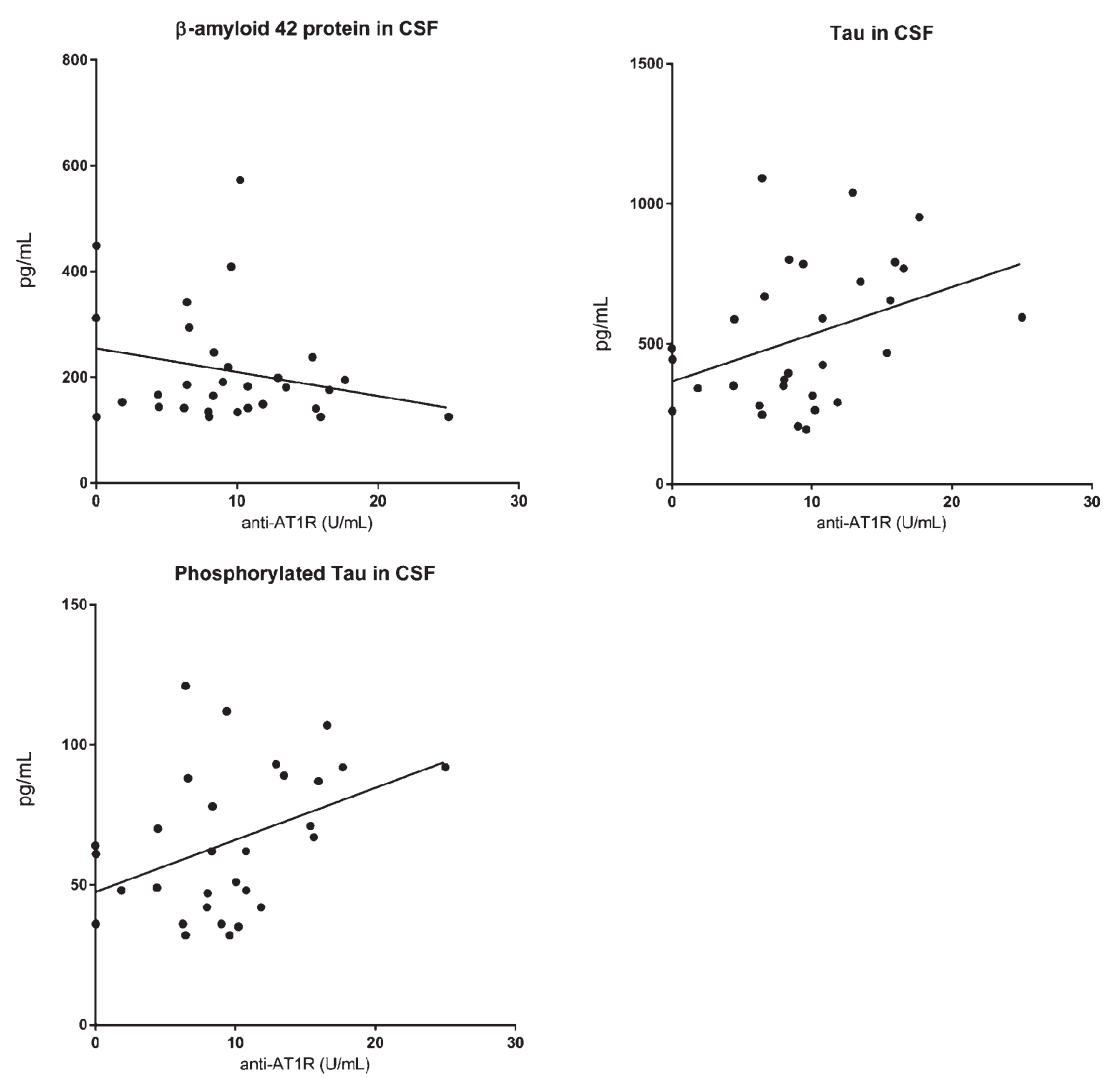

Fig. 3. Anti-AT1R antibodies correlated positively with CSF t-tau and p-tau, but not with CSF A $\beta_{42}(n=30)$.

with or without hypertension, stroke, or cardiac disease within the AD or control group. There was a trend toward lower levels, in AD patients with diabetes, which is contradictory to previous studies. The results were, however, most likely because of low numbers. This indicates that these diseases and potential confounders do not have a large impact on anti-AT1R levels in the two groups. Most studies on anti-AT1R have utilized a cardiomyocyte based functional bioassay or in-house ELISAs utilizing a peptide sequence corresponding to the 2nd extracellular loop. We have used a stable and reproducible assay with the fulllength receptor embedded in a membrane that has a higher sensitivity [30]. Thus, results from previous studies on cardiac disease, diabetes or hypertension might not be directly comparable to our findings.

Various antibodies have been found in AD patient sera and brain tissue, as well as complement activation [31] and cytokine involvement [32,33]. We found a considerable overlap between levels of anti-AT1R antibodies in $\mathrm{AD}$ and controls. Levels of antibodies, in general, increase almost in a linear fashion related to age [34]. Pathological processes leading to AD overlap with several features of normal aging. With increasing age, increased brain $A \beta$, brain atrophy [35], and an increase in oxidative stress [36] have all been described. An increase of anti-AT1R could be associated with aging, which can explain some of the overlap. However, increased levels of antibodies against epitopes expressed in the brain parenchyma may have different functions in AD patients compared to normal aging, due to breakdown of the BBB and increased penetration into the brain [37].

The role of blood pressure in $\mathrm{AD}$ pathogenesis is not clearly understood. Increased midlife blood pressure increases the risk for poor cognitive function and $\mathrm{AD}$ [38], and atherosclerosis and subsequent hypertension are risk factors for AD [5]. Anti-AT1R is associated with hypertension and is a suspected pathogenic factor in preeclampsia [39]. Blood pressure decrease in the time period after AD has been diagnosed [40], and moderate to severe dementia is related to low blood pressure [41]. We found that high anti-AT1R levels were associated with lower blood pressure. There was no difference in antihypertensive drug use that could account for the association. Autonomic dysfunction and impairment in cerebral autoregulation occurs in $\mathrm{AD}$ [42]. However, an altered responsiveness to angiotensin 
II stimulation in $\mathrm{AD}$ has not been demonstrated. The difference was maintained when excluding AD patients with known hypertension or a cardiac disorder, indicating that these confounders did not cause the association. Measurements of blood pressure were done under standard conditions at baseline, so the inverse relationship is unlikely to have arisen by chance. However, we do not know for how long patients have been under treatment for hypertension, which is a potential confounder. A mechanistic relationship that could explain the correlation between low blood pressure and AT1R antibody levels needs to be further investigated.

CSF t-tau and p-tau are elevated in AD and correlate with brain levels of neurofibrillary tangles [43]. In an animal study, infusion of angiotensin II into the brain parenchyma increased the production of $p$-tau through activation of glycogen synthase kinase $3 \beta$ (GSK $3 \beta$ ), the main tau kinase [17]. We found that anti-AT1R levels in serum correlated significantly with both CSF t-tau and CSF p-tau. This could indicate that anti-AT1R crosses the BBB and upregulates GSK $3 \beta$. CSF biomarkers were only available for 30 patients and there were no associations between survival and MMSE decline rate with anti-AT1R levels. In addition, there was no association between anti-AT1R levels and CSF $A \beta_{42}$ or APOE genotype.

Even though increased anti-AT1R levels do not seem to affect $\mathrm{AD}$ progression, they could contribute to an enhanced risk for AD by damaging the cerebral microcirculation, increase neuroinflammation, or penetrate into the brain parenchyma and activate tau kinases [17]. Once AD is clinically detectable, driving forces in the brain might be too strong to be influenced by a functional autoantibody.

In conclusion, we found that $\mathrm{AD}$ is associated with increased levels of anti-AT1R. There was a significant association with CSF t-tau and p-tau and anti-AT1R was inversely associated with blood pressure. Further research is needed to understand the blood pressure response in AD patients with increased levels of antiAT1R and potential mechanisms between anti-AT1R and tau pathology.

\section{ACKNOWLEDGMENTS}

The study received financial support from the Regional Center for Age Related Disease (SESAM), Stavanger University Hospital, The Kavli Trust and Haraldsplass Deaconess Hospital. We want to thank the patients, relatives and research personnel in the DemVest study for their contributions.
Authors' disclosures available online (http://j-alz. com/manuscript-disclosures/15-0053r1).

\section{REFERENCES}

[1] Ballard C, Gauthier S, Corbett A, Brayne C, Aarsland D, Jones E (2011) Alzheimer's disease. Lancet 377, 1019-1031.

[2] Qiu C, Winblad B, Fratiglioni L (2005) The age-dependent relation of blood pressure to cognitive function and dementia. Lancet Neurol 4, 487-499.

[3] Huang CC, Chung CM, Leu HB, Lin LY, Chiu CC, Hsu CY, Chiang CH, Huang PH, Chen TJ, Lin SJ, Chen JW, Chan WL (2014) Diabetes mellitus and the risk of Alzheimer's disease: A nationwide population-based study. PLoS One 9, e87095.

[4] Jacobs V, Woller SC, Stevens S, May HT, Bair TL, Anderson JL, Crandall BG, Day JD, Johanning K, Long Y, Mallender C, Olson JL, Osborn JS, Weiss JP, Bunch TJ (2014) Time outside of therapeutic range in atrial fibrillation patients is associated with long-term risk of dementia. Heart Rhythm 11, 2206-2213.

[5] Hofman A, Ott A, Breteler MMB, Bots ML, Slooter AJC, van Harskamp F, van Duijn CN, Van Broeckhoven C, Grobbee DE (1997) Atherosclerosis, apolipoprotein E, and prevalence of dementia and Alzheimer's disease in the Rotterdam Study. Lancet 349, 151-154.

[6] Luther HP, Homuth V, Wallukat G (1997) Alpha 1-adrenergic receptor antibodies in patients with primary hypertension. Hypertension 29, 678-682.

[7] Fu ML, Herlitz H, Schulze W, Wallukat G, Micke P, Eftekhari P, Sjogren KG, Hjalmarson A, Muller-Esterl W, Hoebeke J (2000) Autoantibodies against the angiotensin receptor (AT1) in patients with hypertension. J Hypertens 18, 945-953.

[8] Hempel P, Karczewski P, Kohnert KD, Raabe J, Lemke B, Kunze R, Bimmler M (2009) Sera from patients with type 2 diabetes contain agonistic autoantibodies against $\mathrm{G}$ proteincoupled receptors. Scand J Immunol 70, 159-160.

[9] Dobrev D, Christ T, Ravens U (2004) Muscarinic subtype-2 receptor autoantibodies: Actors or bystanders in human atrial fibrillation? Eur Heart J 25, 1091-1092.

[10] Lopez-Mejias R, Genre F, Gonzalez-Juanatey C, GonzalezGay MA (2014) Autoantibodies and biomarkers of endothelial cell activation in atherosclerosis. Vasa 43, 83-85.

[11] Karczewski P, Hempel P, Kunze R, Bimmler M (2012) Agonistic autoantibodies to the alpha(1)-adrenergic receptor and the beta(2) -adrenergic receptor in Alzheimer's and vascular dementia. Scand J Immunol 75, 524-530.

[12] Fleegal-DeMotta MA, Doghu S, Banks WA (2009) Angiotensin II modulates BBB permeability via activation of the AT(1) receptor in brain endothelial cells. J Cereb Blood Flow Metab 29, 640-647.

[13] Mogi M, Iwanami J, Horiuchi M (2012) Roles of brain angiotensin II in cognitive function and dementia. Int J Hypertens 2012, 169649.

[14] Hajjar I, Brown L, Mack WJ, Chui H (2012) Impact of Angiotensin receptor blockers on Alzheimer disease neuropathology in a large brain autopsy series. Arch Neurol 69, 1632-1638.

[15] Zhang M, Mao Y, Ramirez SH, Tuma RF, Chabrashvili T (2010) Angiotensin II induced cerebral microvascular inflammation and increased blood-brain barrier permeability via oxidative stress. Neuroscience 171, 852-858.

[16] Zhu D, Shi J, Zhang Y, Wang B, Liu W, Chen Z, Tong Q (2011) Central angiotensin II stimulation promotes beta amyloid production in Sprague Dawley rats. PLoS One 6, e16037. 
[17] Tian M, Zhu D, Xie W, Shi J (2012) Central angiotensin II-induced Alzheimer-like tau phosphorylation in normal rat brains. FEBS Lett 586, 3737-3745.

[18] D'Andrea MR (2003) Evidence linking neuronal cell death to autoimmunity in Alzheimer's disease. Brain Res 982, 19-30.

[19] Aarsland D, Rongve A, Nore SP, Skogseth R, Skulstad S, Ehrt U, Hoprekstad D, Ballard C (2008) Frequency and case identification of dementia with Lewy bodies using the revised consensus criteria. Dement Geriatr Cogn Disord 26, 445-452.

[20] McKhann G, Drachman D, Folstein M, Katzman R, Price D, Stadlan EM (1984) Clinical diagnosis of Alzheimer's disease: Report of the NINCDS - ADRDA Work Group* under the auspices of Department of Health and Human Services Task Force on Alzheimer's Disease. Neurology 34, 939.

[21] Aarsland D, Rongve A, Nore SP, Skogseth R, Skulstad S, Ehrt U, Hoprekstad D, Ballard C (2008) Frequency and case identification of dementia with Lewy bodies using the revised consensus criteria. Dement Geriatr Cogn Disord 26, 445-452.

[22] Sonnesyn H, Nilsen DW, Rongve A, Nore S, Ballard C, Tysnes OB, Aarsland D (2009) High prevalence of orthostatic hypotension in mild dementia. Dement Geriatr Cogn Disord 28, 307-313.

[23] Mulugeta E, Londos E, Hansson O, Ballard C, Skogseth R, Minthon L, Blennow K, Zetterberg H, Aarsland D (2011) Cerebrospinal fluid levels of $\operatorname{sAPP} \alpha$ and $\mathrm{SAPP} \beta$ in Lewy body and Alzheimer's disease: Clinical and neurochemical correlates. Int J Alzheimers Dis 2011, 495025.

[24] Berge G, Sando SB, Rongve A, Aarsland D, White LR (2014) Apolipoprotein E epsilon2 genotype delays onset of dementia with Lewy bodies in a Norwegian cohort. J Neurol Neurosurg Psychiatry 85, 1227-1231.

[25] Banasik M, Boratyńska M, Kościelska-Kasprzak K, Kamińska D, Bartoszek D, Żabińska M, Myszka M, Zmonarski S, Protasiewicz M, Nowakowska B, Hałoń A, Chudoba P, Klinger M (2014) The influence of non-HLA antibodies directed against angiotensin II type 1 receptor (AT1R) on early renal transplant outcomes. Transpl Int 27, 1029-1038.

[26] Giral M, Foucher Y, Dufay A, Van Huyen JPD, Renaudin K, Moreau A, Philippe A, Hegner B, Dechend R, Heidecke H, Brouard S, Cesbron A, Castagnet S, Devys A, Soulillou JP, Dragun D (2013) Pretransplant sensitization against angiotensin II type 1 receptor is a risk factor for acute rejection and graft loss. Am J Transplant 13, 2567-2576.

[27] Du Q, Wu J, Wang H, Wang X, Xu L, Zhang Z, Liu J, Zhang J, Chen J, Hakonarson H, Hu A, Zhang L (2013) Perindopril treatment promote left ventricle remodeling in patients with heart failure screened positive for autoantibodies against angiotensin II type 1 receptor. BMC Cardiovasc Disord 13, 94.

[28] Xia Y, Kellems RE (2013) Angiotensin receptor agonistic autoantibodies and hypertension: Preeclampsia and beyond. Circ Res 113, 78-87.

[29] Zhao L, Xu C, Xu J (2014) Autoantibodies against $\beta 1$ receptor and AT1 receptor in type 2 diabetes patients with left ventricular dilatation. Cardiology 129, 191-196.

[30] Giral M, Foucher Y, Dufay A, Van Huyen JP, Renaudin K, Moreau A, Philippe A, Hegner B, Dechend R, Heidecke H,
Brouard S, Cesbron A, Castagnet S, Devys A, Soulillou JP, Dragun D (2013) Pretransplant sensitization against angiotensin II type 1 receptor is a risk factor for acute rejection and graft loss. Am J Transplant 13, 2567-2576.

[31] Yasojima K, Schwab C, McGeer EG, McGeer PL (1999) Upregulated production and activation of the complement system in Alzheimer's disease brain. Am J Pathol 154, 927-936.

[32] Arosio B, Trabattoni D, Galimberti L, Bucciarelli P, Fasano F, Calabresi C, Cazzullo CL, Vergani C, Annoni G, Clerici M (2004) Interleukin-10 and interleukin-6 gene polymorphisms as risk factors for Alzheimer's disease. Neurobiol Aging 25, 1009-1015.

[33] Sciacca FL, Ferri C, Licastro F, Veglia F, Biunno I, Gavazzi A, Calabrese E, Martinelli Boneschi F, Sorbi S, Mariani C, Franceschi M, Grimaldi LME (2003) Interleukin-1B polymorphism is associated with age at onset of Alzheimer's disease. Neurobiol Aging 24, 927-931.

[34] Nagele E, Han M, Acharya N, DeMarshall C, Kosciuk M, Nagele R (2013) Natural IgG autoantibodies are abundant and ubiquitous in human sera, and their number is influenced by age, gender, and disease. PloS One 8, e60726.

[35] Fjell AM, McEvoy L, Holland D, Dale AM, Walhovd KB (2014) What is normal in normal aging? Effects of aging, amyloid and Alzheimer's disease on the cerebral cortex and the hippocampus. Prog Neurobiol 117, 20-40.

[36] Freeman LR, Keller JN (2012) Oxidative stress and cerebral endothelial cells: Regulation of the blood-brain-barrier and antioxidant based interventions. Biochim Biophys Acta 1822, 822-829.

[37] Sengillo JD, Winkler EA, Walker CT, Sullivan JS, Johnson M, Zlokovic BV (2013) Deficiency in mural vascular cells coincides with blood-brain barrier disruption in Alzheimer's disease. Brain Pathol 23, 303-310.

[38] Kivipelto M, Helkala EL, Laakso MP, Hanninen T, Hallikainen M, Alhainen K, Soininen H, Tuomilehto J, Nissinen A (2001) Midlife vascular risk factors and Alzheimer's disease in later life: Longitudinal, population based study. $B M J$ 322, 1447-1451

[39] Xia Y, Kellems RE (2013) Angiotensin receptor agonistic autoantibodies and hypertension: Preeclampsia and beyond. Circ Res 113, 78-87.

[40] Skoog I, Nilsson L, Persson G, Lernfelt B, Landahl S, Palmertz B, Andreasson LA, Odén A, Svanborg A (1996) 15 -year longitudinal study of blood pressure and dementia. Lancet 347, 1141-1145.

[41] Guo Z, Viitanen M, Fratiglioni L, Winblad B (1996) Low blood pressure and dementia in elderly people: The Kungsholmen project. BMJ 312, 805-808.

[42] den Abeelen AS, Lagro J, van Beek AH, Claassen JA (2014) Impaired cerebral autoregulation and vasomotor reactivity in sporadic Alzheimer's disease. Curr Alzheimer Res 11, 11-17.

[43] Buerger K, Ewers M, Pirttila T, Zinkowski R, Alafuzoff I, Teipel SJ, DeBernardis J, Kerkman D, McCulloch C, Soininen H, Hampel H (2006) CSF phosphorylated tau protein correlates with neocortical neurofibrillary pathology in Alzheimer's disease. Brain 129, 3035-3041. 